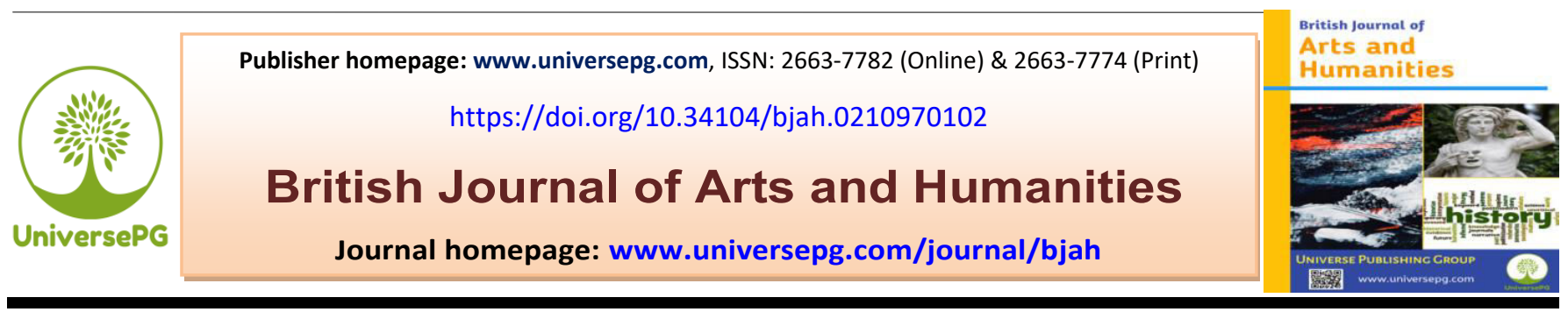

\title{
A Critical Study of The Man-Eater of Malgudi from Ecofeminist Perspectives
}

\section{A.K.M. Masudul Mannan*}

Dept. of English Language and Literature, Jatiya Kabi Kazi Nazrul Islam University, Mymensingh, Bangladesh.

*Correspondence: masudulmannan1234@gmail.com (A.K.M. Masudul Mannan, Lecturer, Dept, of English Language and Literature, Jatiya Kabi Kazi Nazrul Islam University, Mymensingh, Bangladesh).

\section{ABSTRACT}

This article attempts to analyze how R.K. Narayan's The Man-Eater of Malgudi draws a polyphonic picture about woman, life, and the nature of Malgudi from an ecofeminist perspective. It attempts to explore how the theory of ecofeminism that was originally hypothesized in the West is echoed in Narayan's novel The ManEater of Malgudi (1961) based on an Indian setting. This work is an attempt to evaluate and analyze the roles and positions of women and nature that philosophically and phenomenally resembles each other in The ManEater of Malgudi with an ecofeminist approach. Ecofeminism or ecological feminism is now very valid in the academic and literary world. The present paper examines the selected novel under the lens of oriental view towards woman and nature where both are closely associated with each other. Women are victims of degradation, domination, and exploitation, yet they play the role to bring ecological harmony and sustainability. The way Rangi, though oppressed by patriarchy, attempts to save the elephant; Kumar mirrors the purpose of eco-feminism; to create a balance in nature by establishing an inter-cooperative, consistent and unbiased relationship with all creatures of the world irrespective of gender, class, and color. The interrelationship and inter-connectivity between woman and nature are strongly highlighted in this paper through the character Rangi who dismisses Vasu's anti-ecological ventures.

Keywords: Ecofeminism, Criticism, Interdisciplinary education, Man faster, Oriental view and Commodification.

\section{INTRODUCTION:}

Ecocriticism explores and analyzes texts on nature writing to add to the catalogue in literary and cultural studies, environmental awareness in literary texts, illustration of human and non-human relationship and socio-political framework which includes Marxist, Ecofeminist and other approaches for contextualizing cultural and literary works. However, the most important approach within ecocriticism and ecological activism is that of the ecofeminists. In Oxford Advanced Learner's Dictionary, ecofeminism is defined as "a philosophical and political theory and movement which combines ecological concerns with feminists ones regarding both as resulting from the male domiUniversePG I www.universepg.com nation of the society." According to Webster's New World Encyclopedia, "ecofeminism is a movement or theory that applies feminist principles and ideas to ecological issues." it is one of the forms of feminism which has emanated through the amalgamation of feminism and environmentalism. The term 'ecofeminism' was coined by Francoise de Eaubonne in 1974. She used it "to call upon women to lead an ecological evolution to save the planet" (Merchant 184). Ecofeminist analysis examines the cultural, religious, literary, and iconographic ties between women and nature, as well as the parallels between the oppression of nature and the oppression of women. These parallels include, but are not limited to, perceiving women and 
nature as property, men as cultural curators and women as nature curators, and men dominating women and environment (Zein and Setiawan, 2019). Ecofeminists argue that patriarchal society makes ongoing use of women and environment as a source of productivity. Patriarchal society divides society into two genderbased public and private sectors. Men are seen to be totally integrated with the public realm, which is thought to be superior to the private sphere, whereas women are entirely interwoven with the private sphere.

The perception of equating women with nature antecedes to the times of archaic classical mythology. Nature is portrayed as a woman as her fundamental functions encompasses reproduction and nurture. Similarly, women's duties are contemplated as natural to her. Thus, the liaison of nature and women is best described by the phrase: Nature neutralizes women and women feminize nature. One approach to discuss the relationship between women and nature is to interpret the coextensive demeanor they have been wielded into in patriarchal society. Women's role has been to fulfill the demands and aspirations of men. Correspondingly, nature is to have an innate constitution of catering to human needs. Hence, both women and nature are exploited by men leading to a mutual association between oppression of women and deterioration of nature. There has recently been an increase in the connection between environmental and women's issues. Environmental and women's issues have improved at a breakneck pace in recent centuries. As a subset of ecocriticism, ecofeminism asserts that women's difficultties are inextricably linked to biological issues (Akter et al., 2019). It accepts that the oppression of women and the environment cannot be considered inversely.

\section{Literature Review}

Generally, The Man-Eater of Malgudi is interpreted as a story of two antagonists; two male characters, Nataraj and Vasu. Alternatively it has different layers of meanings as Fakrul Alam sees The Man Eater of Malgudi as "a narrative of identification" in his article Plot and Characters in R.K. Narayan's the Man Eater of Malgudi: a Reassessment. Alam finds women characters are less important in this novel and they are only two in numbers: Rangi and Padma. Teresa Hubel identifies Rangi, the female character as 'irresistible' UniversePG I www.universepg.com
(Narayan 115), a "notorious character", "a perfect female animal" (Narayan 82), "the woman to avoid" (Narayan 115) in his article titled Devadashi Defiance and the Man Eater of Malgudi. In an article titled Patterns of Myth and Reality U.P. Sinha compares Rangi to Goddes Kali from mythic dimension. Dr. S.P. Sarswat in his article A portrayal of women characters in R.K. Narayan's Novels: A Critical Study says that Rangi is portrayed negatively in this novel and she is seen from postcolonial views rather from religious perspectives. But she is the eco-friendly character as she does everything to save the temple elephantKumar'. Md. Ali Rayhun Sarker in his article entitled Ecocritical Analysis of $R$. K. Narayan's The Maneater of Malgudi sees Rangi as an eco-friendly character in The Man Eater of Malgudi who is a dependent woman on patriarchal society. She is dependent both economically and physically. Vasu treats her as a sex-slave and no better way than an animal in cage. However, Rangi feels an inner connection between her femininity and animal in nature. That is why she goes to Nataraj to take immediate initiatives to save Kumar, the elephant. Rangi's passionate love for an animal reminds the quote of Kafka "Animals are closer to us than human beings. That is the bars of the cage. We find relations easier with animals than with men." (Corngold, 1996)

\section{Theoretical Framework}

As a branch of feminism, ecofeminism emphasizes a close relationship between women and nature. French writer Francoise d'Eaubonne first coined this term 'Ecofeminism' in her book Le FemisismeOu La Mort, (1974). This movement is a sum of from various social movements, specially, the feminist, the ecology and the peace movements from 1970s to 1980s. The Now, it has become an academic movement that analyses women's lack of power in male dominated society and finds a critical connection between the exploitation of women and the domination of nature. Ecofeminism is not only a combination of a feminist and an environmental theory. Rather, it covers some other ideas. Ecofeminism has given feminism a new light after examining social and environmental problems. It addresses both environmental and social subjects together. In this way, ecofeminism establishes a link between women and environment in religion, literature, Culture 
and iconography. It always advocates against the oppression of women and nature and demands the respect of women as well as nature. This theory asserts that patriarchal society is responsible for the oppression and domination of women, children, and people of color, the poor and all marginalized groups. It criticizes patriarchal society for exploiting natural resources such as animals, land, air, water and so on. This theory can be used to discover the connection between nature and women in culture, literature and religion, and thus address and find out the matches between the oppressions of natural resources and the oppressions of female gender in society. Nature is feminized by men; as women are strictly connected with nature and nature possess the qualities of women. The movement of ecofeminism connects the philosophy of feminism with ecological movement (Faysal and Rahman, 2021). This philosophy shows women, though better than men as women are closely connected with nature, are abused and dominated by man. Women are very closer to the earth and Mother Nature as women go under the process of biological changes in their bodies like ovulation, pregnancy, giving birth menstruation, breast feeding and much more just like nature changes with the cycle of seasons. So, an Eco-feminist writer raises their voice against damage and social injustice against women. Numerous influential texts have been written on this tradition including Women and Nature (Susan Griffin, 1978), Gyn/Eco-logy (May Daly, 1978), the Death of Nature (Carolyn Merchant, 1980). The others writers who have raised their voice for ecofeminism are Vandana Shiva, Rosemary Radford Ruether, Andy Smith, Susan Griffin, Alice Walker and Karen J. Warren. Ecofeminists evaluate the relationship between oppression of women and wildlife by aiming the hierarchies created by mind/body, nature/culture, male/ female and human/non-human binaries.

The aim is to create a non-hierarchical and non-patriarchal world of eco-balance where both women and nature will be protected from the cruel interference of patriarchal society and they live harmoniously with respect and dignity. Ecofeminism is the methodology which explores how woman and nature are presented and treated by society. It examines the interconnectivity between woman and nature in target literary works.

\section{ANALYSIS AND DISCUSSION:}

The parallel marching of the oppression and deprivation of women and the deterioration of nature is conspicuously observed in the novel, The Man-Eater of Malgudi. There are only two female characters in actions. They are Rangi, the most relevant character, and the wife of Nataraj. Another female character is Padma, mother of Rangi. She does not come in action in the novel but we have a scanty account of her. The way in which nature is constructed by the culture and convention of the society is the same way that constructs the idea of a woman. There are some social principles formulated by the male dominated society. These principles form what a woman is and what a woman should be and what a woman should not be. Nataraj constructs his idea regarding Rangi in his own way being influenced by Sastri, as well as by the social norms. According to Nataraj, Rangi is a notorious character of the town. Here he adds the adjective 'notorious' on the basis of the social construction of the idea of Rangi. Even Sastri informs Nataraj in the following manner- "All sorts of low-class women are wondering around this press now a day" (Narayan 84). Here Sastri never takes it in his consideration that these women are being used by the mean-minded male representative of the society. But those male representatives never become talk of the town. They don't become 'notorious' and 'low-class' in the eye of the society. This is parallelly true in respect of the environment and nature. We are using nature and its elements to the fullest extent. We are using them in whatever ways they are most useful to us. Even, we are destroying them at our sweet will. Still, we are imposing negative implication on them. An account of the origin of the Rangies can be relevant here to relate women and nature to the point. Rangi is the daughter of Padma, an old dancer of the temple of God Krishna. According to the narration of Nataraj, Padma is an exemplary, traditional and dedicated woman of the temple who could sing and dance. She is now old and has retired. For many years, Damodar, a wholesaler of grain, was keeping Padma and after this, Rangi was born. Damodar suspected Padma's fidelity and gave her up. But Padma threatened to go to court to prove that he was the father. Finally Damodar had to pay a lot of money to get out of her clutches. Padma is now 
retired. Being old, fat and frightening like the harem guards of Ravana, her daughter Rangi has succeeded her in the temple. Before that Rangi has studied in a school for a while, joined a drama troupe which toured the villages, and come back to the town after seducing all the men folk she had set eyes on. According to Sastri, she is the worst woman who has ever come back to Malgudi. This is how the emergence of Rangi has been narrated by Sastri and accepted and granted by Nataraj. There are some inconsistencies in the narration. The narration is totally biased as it is narrated by the male representatives of the society. Damodar kept Padma for many years without being married to her. Everybody knew it. Then, why Sastri cannot hold Damodar responsible for the same sin that Padma does to survive herself. Sastri of Nataraj does not add any negative adjective to Damodar while they do this in respect of Padma and Rangi. They add the adjectives "notorious", "perfect female animal", "worst" and "seductive" to Rangi. It is reported by Sastri that Damodar paid "a lot of money to get out of her clutches." here the phrase "her clutches" has a negative connotation. Should it be "her clutches" or "his clutches"? So far, the history of the conventions and manners and customs of India is known, there is hardly any case that women dare to seduce men in the Indian subcontinent. Women of the Indian subcontinent have always been shy and reserved. But in the novel, it has been informed we that Rangi has seduced every man folk of the town have "set her eyes on". Is it socially and culturally reliable? This is the representation of women in the male dominated society. This biased representation of women is parallel to the representtation of nature in the society. The human beings are continuously violating the virginity of nature for their own interest. They are threatening the natural environment extensively. When nature sometimes avenge its loss of virginity, we stamped on it different negative connotation without the least thinking. 'man-eater' is such a representation of tiger. Tigers rarely come to the areas of human settlement. Rather people encroach upon the territory of tigers. When threatened in their territory, they resort to killing men. Then, we entitle them as men-eater and give them a "four-nought-five charge". The representation of nature can be suitably exemplified in the talk between Vasu and the forestry

UniversePG I www.universepg.com officer in the press of Nataraj. "Seriously, he is on e of the best forest officers in India. How many times has he been attacked by a rogue elephant? 'Eighteen times' said the man statistically" (Narayan 9). Here, the forestry officer is an intruder in the forest. Still, he thinks that the elephant should not be there because he is more important than the elephant. This anthropocentric view of the ranger induces him to call the elephant "rogue elephant" as Nataraj and Sastri adds different negative adjective to Rangi and Padma. Sometimes, it is seen that we oppress women and keep women under our command to beg trophies from the society. In the novel The Man-Eater of Malgudi, we find many instances of this. Vasu, while taking Nataraj forcefully to the Mempi Forest, opines in the following manner -

"Only fools marry, and they deserve all the trouble they get. I really don't know why people marry at all. If you like a woman, have her by all means. You don't have to won a coffee estate because you like a cup of coffee now and then" (Narayan 33).

His is how he evaluates marriage. This is how he advocates for his notions of marriage and women. He, in this way, supports the birth of women like Rangi and Padma to have them under his male domination throughout their life. The same thing happens in respect of animals, nature and environment. We beg trophies and titles for our cruelties to nature and environment. While flattering the forestry officer, we find such things in the conversation between Vasu and the officer.

"And you just gave it a four-nought-five charge at point blank range?'

'Yes, what else could one do?' asked the hero. 'How many tigers has he tracked down on foot?' 'An average of at least one every half-year,' he said.

'And in thirty years you may guess how much he has done and seen,'

Vasu said. He asked the hero, 'what did you do with all those skins?'

'Oh, presented them here and there,' said the man. 'I don't fancy

Keeping trophies” (Narayan 29). 
A man who has killed at least sixty tigers at the rate of one each half-year is entitled as 'hero' by Nataraj. Jim Corbett, a well-known hunter, killed sixty tigers and we praise his as actions of velour. In Bangladesh, we have got Pochabdi Gazi who is famous for killing tigers. They become legend. Thus we praise the destroyers of nature and environment by bestowing titles and trophies. Rangi is the first person that ex-presses her concern for the life of the elephant, Kumar. She informs Nataraj the plan of Vasu. She tells Nataraj everything in details. But Nataraj suspect her to be an opium eater. Being a woman of the temple, her information gets ruled out as nonsense. Rangi spells out her demeaned status as a woman in the society in an overt way.

"Sir, I am only a public woman, following what is my dharma. I maybe a sinner to you, but I do nothing worse than what some of the so-called family women are doing. I observe our rules. Whatever I may do I don't take opium" (Narayan 121).

As a woman, she wants to serve the society and the social causes in her own ways. But her services are questioned by the patriarchal society. She risks her life to save the elephant and as a reward, she gets the abusive phrase 'female animal'. In this phrase, the attitudes of the society toward the animal and female folk have become crystal clear to us. Here is the connection of the suppression and oppression of women in the society and the deterioration of the nature and environment by the male folk. Malecentrism and anthropocentrism goes together in our male dominated society. Rangi and Padma are the most 'notorious' character in the locality because they earn their living by selling their body and satisfying the demand of the male representatives like Damodar of the society. Rangi is a 'low-class woman' and the 'worst woman' in the society for being the victim of the lust of the male folk. Why should Damodar not be called 'perfect male animal'? People like Damodar are instrumental in getting those women in such professions. Even, Nataraj who is thought to be a self-constrained man is none exception to this. When Rangi comes to inform him about the evil design of Vasu, Nataraj expresses his desire in the following way, "Although Rangi was black as cinders and looked rugged, there was an irresistible physical attraction about her, and I was afraid that I might succumb to her charms. But there was the safety of the grille between us" (Narayan 121).

Nataraj and Damodar have got their lust, and lechery and profligacy are inherent to their instincts. Still they impose those things on the female folk. This is only because of the male centric attitude of the society that male folks are best and can in no way be termed with negative connotation for their activities. Anthropocentrism is parallel to male centrism of the society. Anthropocentrism asserts the idea that human beings are the central creatures of this world. All other creatures are subordinate to them. All other creatures are created only for the welfare of the human being. That's why Vasu declares his anthropocentric right in the following way- "After all we are civilized human beings, educated and cultured, and it is up to us to prove our superiority to nature" (Narayan 17). This anthropocentric mentality leads Vasu to the cruel activities he has been carrying on in the Mempi forest.

\section{CONCLUSION:}

The women-nature connections presented in The Man Eater of Malgudi hold particular importance for cultural feminists are embedded in deep social and psychological structures, resurrection of pre-patriarchal religions and spiritual practices making women's way of knowing and moral reasoning better suited for solving environmental problems. Gynocentric culture and politics are necessary but not sufficient condition for ecofeminism. Rangi shows how to react to the environmental crises. She plays the instrumental role in saving the elephant Kumar. Rangi strongly affirms the view that there is no hierarchical dualism between woman and nature rather both are interrelated and interconnected.

\section{ACKNOWLEDGEMENT:}

I'd like to express my gratitude to Dr. Sheikh Mehedi Hasan, Associate Professor, Dept. of English Language and Literature, JKKNIU, for his helpful suggestions that greatly improved the manuscript.

\section{CONFLICTS OF INTEREST:}

The author declares that there is no conflict of interest. 


\section{REFERRENCES:}

1) Akter MS, Hossain MA, Akter F, Shirin S, and Zalil MA. (2019). A Feministic approach to Nora of Henric Ibsen's A Doll's House, Br. J. Arts Humanit., 1(5), 28-34. https://doi.org/10.34104/bjah.019.28034

2) Alam, F. (1988). Plot and Charactert in R. K. Narayans the Man Eater of Malgudi: A Reassesment, Ariel: A review of International English literature.

3) Alam, F. (2007). Imagining South Asian Writing in English from Bangladesh. South Asian Review, 28(1), 37-49. https://doi.org/10.1080/02759527.2007.11932501

4) Ecofeminism, (2021). Sociology and environmentalism. Retrieved 2 July 2021, from https://www.britannica.com/topic/ecofeminism

5) Ecofeminism, (2021). Encyclopedia.com. Retrieved 12 August 2021, from https://www.encyclopedia.com/places/spain-portug al-italy-greece-and-balkans/malta-political-geograp hy/ecofeminism

6) Faysal YA., and Rahman MM. (2021). Impact of foucauldian discourse on Feminism and postcolonial studies, Br. J. Arts Humanit., 3(1), 1-10. https://doi.org/10.34104/bjah.021010wf10

7) Feminist Environmental Philosophy, (2021). (Stanford Encyclopedia of Philosophy), Retrieved 12 August 2021, from https://plato.stanford.edu/entries/feminism-environ mental/
8) Gaard, G. (1993). Ecofeminism, Philadelphia, Pa.: Temple University Press. pp. 22-23.

9) Gaard, G. (1998). Ecological politics, Philadelphia: Temple University Press. pp. 28-29.

10) Glotfelty, C. (1996). Femininity in the wilderness: Reading Gender in women's guides to backpacking. Women's Studies, 25(5), 439-456. https://doi.org/10.1080/00497878.1996.9979129

11) Hubel, T. (1994). Devadasi Defiance and the Man-Eater of Malgudi. The Journal of Commonwealth Literature, 29(1), 15-28. https://doi.org/10.1177/002198949402900103

12) Kafka, F., \& Bernofsky, S. (2014). The metamorphosis, pp.76- 78. W. W. Norton.

13) Kaur, G. (2013). Postcolonial Ecofeminism in Indian Novels in English. International Journal of Social Science and Humanity, 2(5), 384-390. https://doi.org/10.7763/ijssh.2012.v2.131

14) Narayan, R. (1994). The man-eater of Malgudi, Mysore: Indian Thought Publications, Mysore, pp.1- 182.

15) Oxford English and Spanish Dictionary, (2021). Ecofeminism. Retrieved 12 August 2021, from https://www.lexico.com/definition/ecofeminism

16) Sinha, U. (1988). Patterns of myth and reality, Delhi: Sandarbh Publishers. pp. 77-78.

17) Zein, L., \& Setiawan, A. (2019). General Overview of Ecofeminism, 2. https://doi.org/10.31219/osf.io/fmjgk

Citation: Mannan AKMM. (2021). A critical study of The Man-Eater of Malgudi from ecofeminist perspectives, Br. J. Arts Humanit., 3(4), 97-102. https://doi.org/10.34104/bjah.0210970102 @) () 